\title{
In vitro antiplasmodial activity of flower extracts from Combretum leprosum Mart (mofumbo)
}

\author{
Atividade antiplasmodial in vitro de extratos das flores de Combretum leprosum \\ Mart (mofumbo)
}

\author{
Guilherme Matos Passarini ${ }^{1,}$ Daniel Sol de Medeiros ${ }^{2}$, Dionatas Ulises de Oliveira Meneguetti ${ }^{3}$, \\ Renato Abreu Lima ${ }^{5}$, Valdir Alves Facundo ${ }^{4}$ Patrícia Soares de Maria de Medeiros ${ }^{4}$ \\ ${ }^{1}$ Laboratório de Química de Produtos Naturais da Universidade Federal de Rondônia (UNIR), Porto Velho, RO, Brasil; \\ guilhermepassarini@hotmail.com \\ ${ }_{2}^{2}$ Plataforma de Bioensaios em Malária e Leishmaniose da Fundação Oswaldo Cruz (Fiocruz), Porto Velho, RO, Brasil; \\ ${ }^{3}$ Colégio de Aplicação (CAP) da Universidade Federal do Acre (UFAC), Rio Branco, AC, Brasil; \\ dionatasmeneguetti@hotmail.com \\ ${ }^{4}$ Departamento de Biologia da (UNIR), Porto Velho, RO, Brasil \\ ${ }^{5}$ Universidade Federal do Amazonas, AM, Brasil \\ renatoabreu07@hotmail.com
}

\begin{abstract}
Malaria is the cause of hundreds of thousands of deaths per year, besides putting billions of people at risk of developing disease. When it comes to its therapy, the drugs used currently are losing its efficacy due to increase in the frequency of resistant strains of the parasite, highlighting the importance for the search of new classes of molecules presenting antiplasmodial activity. In the present work, the antiplasmodial activities of five extracts (crude, hexane, chloroform, ethyl acetate and methanol) from the flowers of Combretum leprosum are assessed. The method employed for obtaining the extracts was silica gel column chromatography, and the techniques used for the analysis of antiplasmodial activity $\left({ }_{50}\right)$ and citotoxicity $\left(M L D_{50}\right)$ were ELISA and MTT respectively, where a selectivity index was calculated after the obtaining of these two values. The extract presenting the highest antiplasmodial activity was the chloroform extract $\left(I C_{50}=3.97 \mu \mathrm{g} / \mathrm{mL}\right)$, however, this extract also presented the higher cytotoxicity $\left(M L D_{50}=18.12 \mu \mathrm{g} / \mathrm{mL}\right)$, and therefore the extract presenting the best overall activity was the methanolic extract $(I S=18.97)$. The study demonstrated the plant Combretum leprosum has active substances against P. falciparum and therefore is a potential to be explored in further pharmacological studies with this parasite.
\end{abstract}

Keywords: Malaria; Chemotherapy; Plants

\section{Resumo}

A malária é responsável por milhares de mortes por ano, além de bilhões de pessoas estarem sob o risco de desenvolvêla. Quanto à sua terapia os fármacos utilizados atualmente estão perdendo a eficácia devido ao aumento na frequência e cepas resistentes do parasita, e esse fato ressalta a importância da busca por novas classes de moléculas com atividade antiplasmodial. O presente estudo objetivou analisar a atividade antiplasmodial de cinco extratos (bruto, hexânico, clorofórmico, acético e metanólico) das flores da planta Combretum leprosum. A metodologia empregada para a obtenção dos extratos foi a cromatografia em silica gel, e as técnicas empregadas para a análise da atividade antiplasmodial (IC50) e citotoxicidade (MDL50), respectivamente, foram ELISA e MTT, sendo calculado um indice de seletividade (IS) após a obtenção dos dois valores. O extrato que apresentou a maior atividade antiplasmodial foi o clorofórmico (IC50=3,97 $\mu \mathrm{g} / \mathrm{mL}$ ), contudo, este apresentou alta citotoxicidade (MDL50=18,12 $\mu \mathrm{g} / \mathrm{mL}$ ), e foi considerado que o extrato que apresentou o melhor IS foi o do extrato metanólico $(I S=18,97)$. O estudo demonstrou que a planta Combretum leprosum possui substâncias ativas contra Plasmodium falciparum e, portanto, constitui-se em um potencial a ser explorado em estudos farmacológicos posteriores com este parasita.

Palavras-chave: Malária; Quimioterapia; Plantas 


\section{Introdution}

Over 3 billion people are estimated to be at risk of being infected with malaria and therefore developing disease, and according to latest estimates, hundreds of thousands of deaths caused by it occurred in each year of this millennium (WHO, 2014). The world region that suffers the heaviest burden is Africa, where the great majority of cases of malaria occur, mainly in children under the age of five (WHO, 2014). The disease is caused by parasitic protozoa of the genus Plasmodium, of which five species are known to infect humans: P. falciparum, P. vivax, P. malariae, P. ovale, and P. knowlesi (COX, 2010). The parasite life cycle begins when a female mosquito of Anopheles genus bites a human and releases the sporozoites from its salivary glands to the dermis, where they reach the avascular tissue and then a percentage of them migrates and enters the blood vessels, making their way to the liver, where they undergo cellular modifications and perform rounds of asexual replication (ALY; VAUGHAN; KAPPE, 2009).

After leaving the liver, the parasite begins other cycles of asexual replication inside red blood cells, using molecules and cellular structures of the host cells to survive, grow and reproduce, generating thousands of merozoites and causing the characteristic symptoms of the disease (TILLEY; DIXON; KIRK, 2011). When it comes to its chemotherapy, most of the cases of uncomplicated malaria are treated currently by the use of ACT's drugs, although is already known that these drugs are losing its efficacy due to the increase in frequency of resistant strains (VISSER; VUGT; GROBUSCH, 2014), which highlights the importance for the search of new molecules bearing antiplasmodial activity.

Plants have been used during millennia by humanity, and pharmacological studies of medicinal plants yielded useful molecules in the treatment of various diseases, including malaria (GINSBURG; DEHARO, 2011), and despite the great number of existing species of plants, just a small percentage of them have been characterized pharmacologically, making the biodiversity of world's flora a great potential to be explored (DERDA; HADÁS, 2015). Data in literature show that over 1200 species of plants, belonging to 160 families, are used to treat malaria and fever, and on average, a fifth of the patients with malaria in endemic countries use traditional medicines to treat the disease (WILLCOX; BODEKER, 2004).

Combretum leprosum is a scandent shrub or liana plant that can be found in Brazil, Paraguay and Bolivia. Some of the distinctive features of the species are the opposite leaves, 4-winged fruit and panicle inflorescences (LOIOLA et al., 2009). Local populations in the northeast region of Brazil use some of its parts as expectorants, to treat coughs and to staunch blood flow (AGRA et al., 2007; SILVA; BARROS; NETO, 2015). In this context, The aim of this study is to assess the antiplasmodial potential of $C$. leprosum flower extracts against $P$. falciparum in vitro.

\section{Material and Methods}

\section{Obtaining and preparation of the extracts}

Flowers of C. leprosum were collected in Viçosa, State of Ceará, in May 2001. They were properly dried and grinded and after dipped in ethanol (99\%) for the extraction. The drying of the extract was performed by rota-evaporation and part of it was subjected to a chromatographic column with silica gel as standing phase (SASIDHARAN et al., 2011), whereas the other part constituted the crude extract (CLCrE). The solvents used were hexane, chloroform, ethyl acetate and methanol for the obtaining of the following extracts: Hexane extract (CLHE); Chloroform extract (CLClE); Ethyl Acetate extract (CLEAE) and methanol extract (CLME). For the carrying out of cytotoxic and antiplasmodial tests, extracts were solubilized with ethanol, where all solutions were performed at the moment of the biological experiments.

\section{In vitro Antiplasmodial tests against $P$. falciparum}

The chloroquine-resistant strain (W2) was cultured in human red blood cells as established by Trager and Jensen (1976) with modifications, using a protocol previously established and standardized by Laboratório de Malária do Centro de Pesquisas René Rachou (DE ANDRADE-NETO et al., 2004). The predominance of rings in the culture was accomplished by using sorbitol, according to literature (LAMBROS; VANDERBERG, 1979), and the hematocrite and parasitemia adjusted by the addition of red blood cells. Culture of synchronized parasites was distributed in microplates containing culture medium and red blood cells. Before the addition of the parasites, the drugs were added in serial dilutions. For the negative control, no drug was added to the infected red blood cells, and for the positive control, chloroquine was added to the parasite culture. In the ELISA test (NOEDL et al., 2002), two plates were prepared: one of them (the test plate) containing the parasites and drugs, and the other one containing the antibodies. The test plate was incubated for 72 hours, wherein the negative control was withdrawn 24 hours for 
being used as background. After 72 hours, the plates were frozen and thawed twice for the lysis of the red blood cells. For the sensibilization of the test plates, the primary antibody was added (MPFM-55A ICLLAB®, EUA). Wells were washed and incubated, and for each well was added $100 \mu \mathrm{L}$ of the samples of $P$. falciparum hemolyzed culture and at six wells of the plates corresponding to the background was added $100 \mu \mathrm{L}$ of negative controls. The plate was incubated during one hour in moist chamber and washed three times, adding to each well $100 \mu \mathrm{L}$ of the secondary antibody (MPFG55P ICLLAB ${ }^{\circledR}$, EUA). After incubation in moist chamber, the plate was incubated during 5 to 10 minutes at room temperature, and the reaction was stopped with the addition of sulfuric acid. The reading was performed by a spectrophotometer of microplates (ELISA reader). The inhibition of $50 \%$ of the parasite growth $\left(\mathrm{IC}_{50}\right)$ was determined by dose-response curves, through linear regression, using the program Origin.

\section{Citotoxicity assays in vitro on HepG2 cells}

Human cell line HepG2 was cultured as recommended (CALVO-CALLE et al., 1994). Cells were cultured in culture bottles, with culture medium (RPMI) and gentamicin. They were maintained in an incubator and its medium was replaced each two days. For the preparation of the plates, they were washed with incomplete medium and treated in tripsin-EDTA and incubated for the detachment of the cells from the culture bottle. After, the complete RPMI medium was added, followed by centrifugation at room temperature. The supernatant was discarded and the sediment resuspended in RPMI. After the preparation of the plates was added MTT (Sigma Aldrich) in the plates (DENIZOT; LANG, 1986). After incubation with MTT, supernatant was withdrawn and the dye at the bottom of the wells diluted with DMSO in a volume of $100 \mu \mathrm{L} /$ well. The microplates were read by an ELISA reader using a filter of $570 \mathrm{~nm}$. The Minimum Lethal Dose of $50 \%$ of cells $\left(\mathrm{MLD}_{50}\right)$ was also determined by the program Origin (OriginLab Corporation, Northampton, MA, EUA).

\section{Selectivity Index}

The Selectivity Index (SI) was calculated as a quotient of the $\mathrm{MLD}_{50}$ and $\mathrm{IC}_{50}$ values. If the SI was lower than 10, the extract was considered toxic; if the value was higher than 10, it was considered non- toxic (WENIGER et al., 2001).

\section{Results and Discussion}

All of the extracts assayed in this study exhibited antiplasmodial activities to some degree (Table 1). . Despite its high antiplasmodial activity, the chloroform extract $\left(\mathrm{IC}_{50}=3.97 \mu \mathrm{g} / \mathrm{mL}\right)$ also showed great toxicity for the human cell line HepG2 $\left(\mathrm{MLD}_{50}=18.12 \mu \mathrm{g} / \mathrm{mL}\right)$ (Table 1). However, the subsequent fractioning of this extract will be needed in order to assess the cytotoxic and antiplasmodial activities of its molecules, so one can verify whether the molecule presenting the highest antiplasmodial activity in this extract is also the main cause for the toxicity observed towards HepG2 cells. The extract that presented the best overall activity was the methanolic extract (SI = 18.97), despite it did not present neither the highest antiplasmodial activity nor the lower citotoxicity (Figure 1)

Table $1-\mathrm{IC}_{50^{\prime}}, \mathrm{MLD}_{50}$ and SI of C. leprosum flower extracts

\begin{tabular}{c|c|c|c|c}
\hline Drug & IC50 $(\mu \mathrm{g} / \mathrm{mL})$ & MLD50 $(\mu \mathrm{g} / \mathrm{mL})$ & SI & RESULT \\
\hline CLCrE & 25.25 & 246.74 & 9.77 & Inactive/Toxic \\
\hline CLHE & 12.20 & 168.89 & 13.84 & Active/Non toxic \\
\hline CLClE & 3.97 & 18.12 & 4.56 & Inactive/Toxic \\
\hline CLEAE & 11.46 & 123.66 & 10.79 & Active/Non toxic \\
\hline CLME & 5.89 & 111.74 & 18.97 & Active/Non toxic \\
\hline CQ & 0.04 & 297 & 7425 & Active/Non toxic \\
\hline
\end{tabular}

IC50: Concentration causing 50\% inhibition, MLD50 : Dose lethal to 50\% of the population 

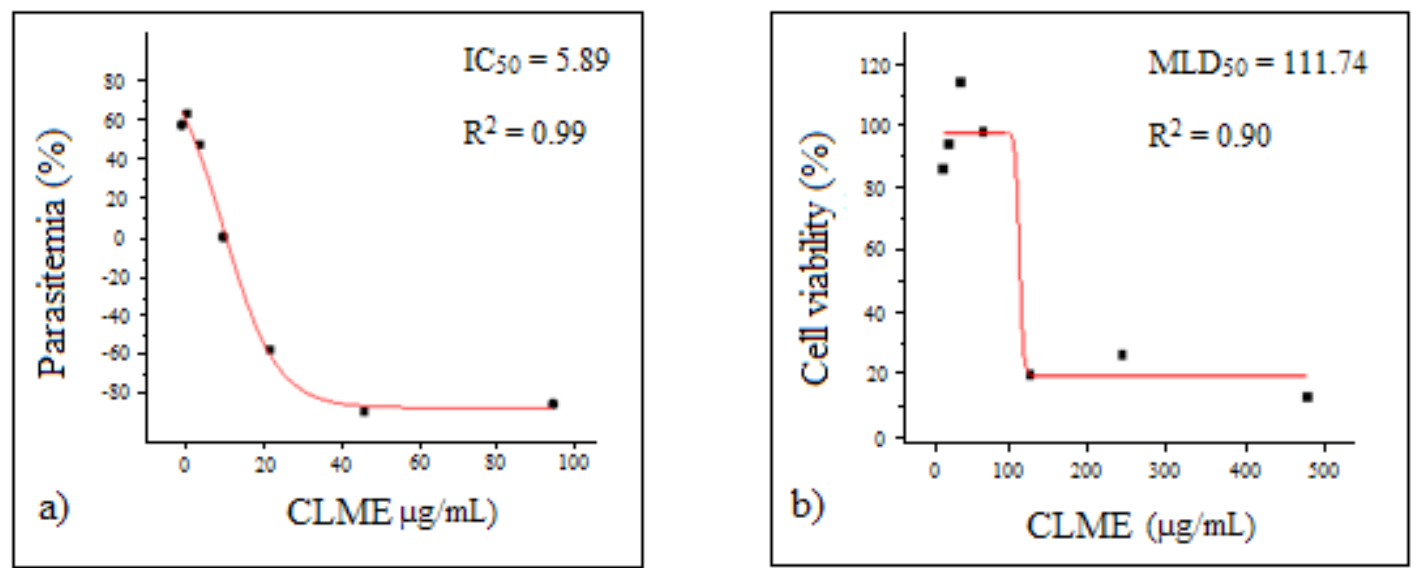

Figure 1 - Dose-response relationship curve of the methanolic extract (the extract presenting the higher SI) of the antiplasmodial (a) and citotoxicity (b) tests, respectively.

Most of the pharmacological studies of $C$. leprosum report activities against non-infectious pathological processes, such as neurodegenerative diseases (FACUNDO et al., 2005), ulceration (NUNES et al., 2009) and snake venom intoxication (FERNANDES et al., 2014). However, in a study performed by Teles and co-workers (2011), where from the fruits of $C$. leprosum were tested the ethanolic extract and a lupane, an antileishmanial activity was reported. The ethanolic extract showed an $\mathrm{IC}_{50}$ of $24.8 \mu \mathrm{g} / \mathrm{mL}$. This result was similar to that of our study, in which the crude extract, also extracted with ethanol, obtained an $\mathrm{IC}_{50}$ of $25.70 \mu \mathrm{g} / \mathrm{mL}$. The lupane exhibited an $\mathrm{IC}_{50}$ of $3.3 \mu \mathrm{g} / \mathrm{mL}$. The ethanolic extract was tested on a $25 \mu \mathrm{g} / \mathrm{mL}$ concentration and the lupane was tested on a $5 \mu \mathrm{g} /$ $\mathrm{mL}$ for citotoxicity. On these concentrations, neither the extract nor the lupane were toxic (TELES et al., 2011). The citotoxicity result of the ethanolic extract for Leishmania is also in agreement with our work. Further studies using the lupane against Leishmania were carried out for investigation of the activity of a liposomal formulation carrying the substance (BARROS et al., 2013) and for its interference in amastigote replication inside mammal cells, as well as investigation of its action mechanism through bioinformatics tools (TELES et al., 2015). This study, therefore, contributes to the understanding of the antiprotozoal activites of C. leprosum.

Species of the genus Combretum have already been investigated in respect to its pharmacological activities against non-infectious and infectious diseases, including antiplasmodial activities for some of these species (LIMA et al., 2012; ROY et al., 2014). Furthermore, some of them are used in traditional medicine to treat malaria and fever (TABUTI, 2008; TRAORE et al., 2013; DIARRA et al., 2015; AGBOEKA e al., 2016). The activity of our methanolic extract $\left(\mathrm{IC}_{50}=5.89 \mu \mathrm{g} / \mathrm{mL}\right)$ was similar to that presented by C. molle methanolic extract $\left(\mathrm{IC}_{50}=5.7 \mu \mathrm{g} / \mathrm{mL}\right)$, which was extracted from its leaves. The citotoxicity value was significantly different $\left(\mathrm{MLD}_{50}=40.3 \mu \mathrm{g} / \mathrm{ml}\right.$ in K562S human monocyte cell line), possibly due to the use of a different cell line (GANSANÉ et al., 2009).

An acetonic eluate, extracted from the bark of the stem of Combretum molle showed great activity against erythrocytic forms of $P$. falciparum, presenting an $\mathrm{IC}_{50}$ of $8.17 \mu \mathrm{g} / \mathrm{mL}$. The citotoxicity of this extract in $\mathrm{KB}$ cells was $86 \mu \mathrm{g} / \mathrm{mL}\left(\mathrm{MLD}_{50}\right.$ ), resulting in an SI of 10.5 (ASRES et al., 2001). In a study done by Moosophon and coworkers, four flavanes isolated from the stems of Combretum griffithii showed the following antiplasmodial activities (15.74, $13.04,9.66$, and $14.45 \mu \mathrm{g} / \mathrm{mL}$ of $\mathrm{IC}_{50}$ ), although it's respective toxicities to cell lines were significantly high. A dichloromethane extract of $C$. sericum leaves resulted in a low $\mathrm{IC}_{50}(9 \mu \mathrm{g} / \mathrm{ml})(\mathrm{MOOSOPHON}$ et al., 2013). Niass and co-workers (2016) tested three medicinal plants, amongst them, Combretum glutinosum, against $P$. falciparum. Five extracts from this plant were assayed (ethyl acetate, $\mathrm{IC}_{50}=41 \mu \mathrm{g} / \mathrm{mL}$; diethyl ether, IC $50=65 \mu \mathrm{g} / \mathrm{mL}$; chloroform, $\mathrm{IC}_{50}=38 \mu \mathrm{g} / \mathrm{mL}$; metanol, $\mathrm{IC}_{50}=45 \mu \mathrm{g} / \mathrm{mL}$, and methanol $/$ water, $\mathrm{IC}_{50}=35 \mu \mathrm{g} / \mathrm{mL}$ ), of which none of them resulted in an $\mathrm{IC}_{50}$ lower than $10 \mu \mathrm{g} / \mathrm{mL}$.

The ethanolic extract of the leaves of $C$. molle presented an $\mathrm{IC}_{50}$ value of $25 \mu \mathrm{g} / \mathrm{mL}$, being very similar to the $\mathrm{IC}_{50}$ value of the crude extract of our work $(25.25 \mu \mathrm{g} / \mathrm{mL})$ (TRAORE-COULIBALY et al., 2013). Another study performed in 2013 with medicinal plants of Burkina Faso, in which are included Combretum collinum, showed very promising results. A chloroform extract obtained from the leaves of this species resulted in an $\mathrm{IC}_{50}=0.2 \mu \mathrm{g} / \mathrm{mL}$, with a $\mathrm{SI}=140$. An extract containing only alkaloids, extracted with chloroform resulted in an $\mathrm{IC}_{50}=0.4 \mu \mathrm{g} / \mathrm{mL}$ and a SI of 113. 6 (SANON et al., 2013). These studies show the genus has a great pharmacological potential to be explored in the antimalarial therapy.

Although the isolation of an active principle was not carried out, it is likely that the molecule presenting the highest antiplasmodial activity is a triterpene, since compounds of this class have several studies reporting its antiplasmodial activities (NOGUEIRA; LOPES, 2011; RAMALHETE et al., 2011; RAMALHETE et al., 2014) and this 
chemical class seems to be the most abundant in species of the genus Combretum (DAWE et al., 2013) and in the species C. leprosum (FACUNDO et al., 1993; FACUNDO et al., 2008). Triterpenes that were isolated from the genus Combretum also showed activities against another microorganisms, like fungi (BISOLI et al., 2008), bacteria (ANGEH et al., 2007a; ANGEH et al., 2007b; SONGCA, RAMURAFHI; OLUWAFEMI, 2013), viruses (ASRES; BUCAR, 2005) and other species of parasites (TELES et al., 2011; HAAVIKO et al., 2014).

\section{Conclusions}

The species C. leprosum has active substances against $P$. falciparum W2 strain in vitro, and despite the highest antiplasmodial activity was presented by the chloroform extract, it also showed high toxicity towards the human cell line HepG2. However, only the subsequent fractioning of this extract can identify what substances are the causes for each of these effects identified in the present study. Within this context, new research is needed in order to improve the knowledge about the activity of the molecules of this plant, such as the isolation and characterization of the active principle and in vivo tests with the extracts and/or the isolated substance, aiming the identification of a new molecule with potential to be used in antimalarial therapy.

\section{Acknowledgements}

We are grateful to Universidade Federal de Rondônia for the scholarship concession and Fundação Oswaldo Cruz - RO for the opportunity of carrying out this study.

\section{References}

Agboeka K et al. Ethnobotanical Study of Medicinal Plants Used for the Treatment of Malaria in the Plateau Region, Togo. Pharmacognosy Res 2016; 8(Suppl 1): S12-S18.

Agra MF et al. Medicinal and poisonous diversity of the flora of "Cariri Paraibano", Brazil. J Ethnopharm 2007; 111: 383-395.

Aly ASI, Vaughan AM, Kappe SHI. Malaria Parasite Development in the Mosquito and Infection of the Mammalian Host. Annu Rev Microbiol 2009; 63: 195-221.

Andrade-Neto VF et al. Antimalarial activity of phenazines from lapachol, $\beta$-lapachone and its derivatives against Plasmodium falciparum in vitro and Plasmodium berghei in vivo. Bioorg Med Chem Lett 2004; 14(5): 11451149.

Angeh JE et al. Antimicrobial and anti-inflammatory activity of four known and one new triterpenoid from Combretum imberbe (Combretaceae). J Ethnopharm 2007a; 110(1): 56-60.

Angeh JE et al. Novel antibacterial triterpenoid from Combretum padoides [Combretaceae]. Arkivoc 2007b; 9: 113120 .

Asres K et al. In vitro Antiprotozoal Activity of Extract and Compounds from the Stem Bark of Combretum molle. Phytother Res 2001; 15: 613-617.

Asres K, Bucar F. Anti-HIV activity against immunodeficiency virus type 1 (HIV-I) and type II (HIV-II) of compounds isolated from the stem bark of Combretum molle. Eth Med J 2005; 43(1): 15-20.

Barros NB et al. Liposomal-lupane system as alternative chemotherapy against cutaneous leishmaniasis: Macrophage as target cell. Exp Parasitol 135(2): 337-343.

Bisoli E et al. Bioactive Pentacyclic Triterpenes from the Stems of Combretum laxum. Molecules 2008; 13: 27172728. 
Calvo-Calle J et al. In vitro development of infectious liver stages of $P$. yoelii and $P$. berghei malaria in human cell lines. Exp Parasitol 1994; 79(3): 362-373.

Cox FEG. History of the discovery of the malaria parasites and their vectors. Parasites \& Vectors 2010; 3(5): 1-9

Dawe A et al. Phytochemical constituents of Combretum Loefl. (Combretaceae). Pharm Crops 2013; 4:38-59.

Derda M, Hadás E. The use of phytotherapy in diseases caused by parasitic protozoa. Acta Parasitologica 2015; 60(1):1-8.

Denizot F, Lang R. Rapid colorimetric assay for cell growth and survival: Modifications to the tetrazolium dye procedure giving improved sensitivity and reliability. J Immunol Meth 1986; 89: 271-277.

Diarra N et al. Ethnobotanical study of plants used against malaria in Sélingué subdistrict, Mali. J Ethnopharm 2015; 166: 352-360.

Facundo VA et al. Triterpenes and flavonoids from Combretum leprosum. Phytochem 1993; 32(2):411-415.

Facundo VA et al. Arjunolic acid in the ethanolic extract of Combretum leprosum root and its use as a potential multi-functional phytomedicine and drug for neurodegenerative disorders: anti-inflammatory and anticholinesterasic activities. J. Braz. Chem. Soc. 2005; 16(6b): 1309-1312.

Facundo VA et al. Two new cycloartanes from Combretum leprosum Mart. (Combretaceae) Rev Lat Quim 2008; 36(3):76-82.

Fernandes FFA et al. Counteraction of Bothrops snake venoms by Combretum leprosum root extract and arjunolic acid. J Ethnopharm 2014; 155(1): 552-562.

Gansané A et al. Antiplasmodial activity and toxicity of crude extracts from alternatives parts of plants widely used for the treatment of malaria in Burkina Faso: contribution for their preservation. Parasitol Res 2010; 106(2): 335-340.

Ginsburg H, Deharo E. A call for using natural compounds in the development of new antimalarial treatmentsan introduction. Malaria J 2011; 10 Suppl 1: 1-7.

Haavikko R. et al. "Heterocycle-fused lupane triterpenoids inhibit Leishmania donovani amastigotes." Med Chem Comm 2014; 5(4): 445-451.

Lambros C, Vanderberg J. Synchronization of Plasmodium falciparum erythrocytic stages in culture. J Parasitol 1979: 418-420.

Lima GRM et al. Bioactivities of the Genus Combretum (Combretaceae): A Review. Molecules 2012; 17(8): $9142-9206$

Loiola MIB, Rocha, EA, Baracho, GS, Agra, MF. Flora da Paraíba, Brasil: Combretaceae. Acta bot. bras. 2009; 23(2):330-342.

Moosophon P et al. Antiplasmodial and Cytotoxic Flavans and Diarylpropanes from the Stems of Combretum griffithii. J Nat Prod 2013; 76(7): 1298-1302.

Niass O et al. In Vitro Assessment Of The Antiplasmodial Activity Of Three Plants Extracts Used In Local Traditional Medicine In Saloum (Senegal). Europ Scientif J 2016; 12(12): 157-165.

Noedl HC et al. Plasmodium falciparum: effect of anti-malarial drugs on the production and secretion characteristics of histidine-rich protein II. Exp Parasitol 2002; 102(3): 157-163.

Nogueira CR, Lopes LMX. Antiplasmodial Natural Products. Molecules 2011; 16(3): 2146-2190. 
Nunes PHM et al. Antiulcerogenic activity of Combretum leprosum. Pharmazie 2009; 64: 58-62.

Ramalhete C et al. Karavilagenin C derivatives as antimalarials. Bioorg Med Chem 2011; 19(1): 330-338.

Ramalhete $\mathrm{C}$ et al. Dual-stage triterpenoids from an African medicinal plant targeting the malaria parasite. Bioorg Med Chem 2014; 22(15): 3887-3890.

Roy $\mathrm{S}$ et al. COMBRETUM (COMBRETACEAE): BIOLOGICAL ACTIVITY AND PHYTOCHEMISTRY. Indo Am J Pharm Res 2014; 4(11): 5266-5299

Sanon $\mathrm{S}$ et al. In vitro antiplasmodial and cytotoxic properties of some medicinal plants from western Burkina Faso: original research. Afr J Lab Med 2013; 2(1):1-7.

Sasidharan S et al. Extraction, isolation and characterization of bioactive compounds from plants' extracts. Afr J Trad, Compl \& Alt Med 2011; 8(1):1-10.

Silva MP, Barros RFM, Neto JMM. Farmacopeia natural de comunidades rurais no Estado do Piauí, Nordeste do Brasil. Desenvolv. Meio Ambiente 2015; 33: 193-207.

Songca SP, Ramurafhi E, Oluwafemi OS. A pentacyclic triterpene from the leaves of Combretum collinum Fresen showing antibacterial properties against Staphylococcus aureus. Afr J Biochem Res 2013; 7(7): 113-121.

Tabuti JRS. Herbal medicines used in the treatment of malaria in Budiope county, Uganda. J Ethnopharm 2008; 116:33-42.

Teles CBG et al. Activity of the Lupane Isolated from Combretum leprosum against Leishmania amazonensis Promastigotes. J Braz Chem Soc 2011; 22(5): 936-942.

Teles CBG et al. A lupane-triterpene isolated from Combretum leprosum Mart. fruit extracts that interferes with the intracellular development of Leishmania (L.) amazonensis in vitro. BMC Compl Alt Med 2015; 15(165): 1-10.

Tilley L, Dixon MWA, Kirk K. The Plasmodium falciparum infected red blood cell. Int J Biochem Cell Biol 2011; 43(6): 839-842.

Trager W, Jensen JB. Human malaria parasites in continuous culture. Science 1976; 193(4254): 673-675.

Traore MS et al. Ethnobotanical survey on medicinal plants used by Guinean traditional healers in the treatment of malaria. J Ethnopharm 2013; 150: 1145-1153.

Traoré-Coulibaly $\mathrm{M}$ et al. Antiplasmodial and repellent activity of indigenous plants used against malaria. J Med Plants Res 2013; 7(42): 3105-3111.

Vissser BJ, Vugt M, Grobusch MP. Malaria: an update on current chemotherapy. Exp Opin Pharmacother 2014; 15(15): 1-36.

Weniger B et al. Antiprotozoal activities of Colombian Plants. J Ethnopharm 2001; 78: 193-200.

Willcox ML, Bodeker G. Traditional herbal medicines for malaria. BMJ 2004; 329: 1156-1159

WHO: World Malaria Report 2014. Geneva: World Health Organization, p. 227, 201. 